\title{
The Effect of Economic Policies on Albanian GDP
}

\author{
Prof. As. Alqi Naqellari \\ Lecturer at Mediterranean university of Albania \\ Prof. As. Pashk Leka \\ Lecturer at Mediterranean university of Albania \\ Msc. Ferjolt Ozuni \\ Lecturer at Mediterranean university of Albania
}

\section{Doi:10.5901/ajis.2016.v5n3p55}

\begin{abstract}
Policies applied nowadays are fiscal policy, monetary policy, income policy, and foreign relations policy, etc. This paper will analyze fiscal and monetary policy. How have those policies affected in the Albanian GDP in 2004-2015. The goal is to determine which of these policies is effective in economic growth and where we should aim in the future. Reached conclusion is simple, fiscal policies have limited impact on the growth of GDP. This is consistent with the theoretical model of a small open economy with a flexible exchange rate regime. Monetary policies have lower impacts on economic growth. This conclusion is contrary to theoretical impact on GDP. In the theoretical model, the monetary policies are fully effective in GDP growth, while fiscal policies have limited impact. This paper used the methods of analysis and synthesis, comparison of the description, are also used statistical methods.
\end{abstract}

Keywords: GDP, economic Growth, Budget Deficit, Exchange Rates, trade deficit.

\section{Introduction}

Before 1990, the Albanian economy has been a closed economy. After 1990 it was turned into an open economy. During 2010-2014 \{openness (export + import) / GDP\} was respectively 52.3\%, 56.1\%, 53.4\%, 56.4\% and 57.2\%. Despite the opening rate is low, the most products basket of Albania is provided by trade. In an economic model similar of Albania, theoretically has affect monetary policy and fiscal policy has less impact.

\section{Literature Use: (Theoretical Model of a Small Open Economy and the Impact of Economic Policies on GDP.)P}

To analyze the effects of monetary and fiscal policies in the Albanian economy is necessary to first determine the economic model. Albanian economy model is the model of a small open economy with flexible exchange rates. Economy is small because any change in the interest rate is not reflected in international markets. It is open after the free movement of capital from abroad and from inside to outside economy. There is no consistency between the revenue and expenditure of the interior. The exchange rate is flexible because it is not determined by the Central Bank of Albania. We will do the analysis using the IS-LM curves, their displacement from the implementation of monetary and fiscal policies. We will take into account the Mundell-Fleming model. There are four authors that will utilize, Gregory Mankiw, Sanjay Rode, Bernier and Yves Bernard Simon.

According to Gregory Mankiw, Macroeconomics. The effects of monetary and fiscal policy are as follows: The effect of fiscal policy.

The model is constructed by placing the axis $Y$ 's exchange rate, the axis $X$ ' $s$ real GDP (Y). LM curve in this situation appears as a fully vertical curve. It is insensitive to changes in the exchange rate. It is sensitive to rate changes (i) interest. IS curve is sensitive to the exchange rate. Directions on a slope is negative. In this way the model has this shaped (Fig no. 1).

Any increase in the components of GDP $(Y)$ shifts the IS curve to the right and vice versa, each landing IS curve 
shifts to the left. This is because the exchange rate affects the elements of $Y$. Any change in the exchange rate does not affect the displacement of curve LM.

\section{Correlative Indicators Connection between Fiscal Policy and GDP}

We will suppose that the government will apply an expansion policy. What will happen with government spending in the area of investment, will cut the number of taxes or tax rate cut? In the first case it will increase $G$ and curve will shift to the right, in the second and third will increase $\mathrm{C}$ and I. Consequently IS curve will shift back in the right. In both cases the displacement curve will not result in the growth of $Y$, but will bring a change in the exchange rate.

An increase in government spending or decrease in the tax rate will bring IS * curve shifts to the right. This will increase the exchange rate but will not change the equilibrium level of income.

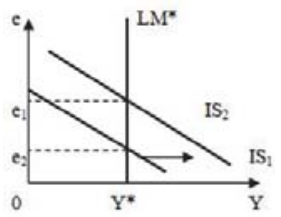

Figure No. 1. Impact of fiscal policy

Capital flow will increase the demand for money in the market, to be exchanged for euro and dollar. It will put the exchange rate of the domestic currency. The assessment of the exchange rate will make domestic goods relatively more expensive than foreign goods and it will cut net exports. Reduction of net exports will exert pressure expansionary effect of fiscal policy on income. It will negatively affect economic growth. The same phenomenon will happen even if fiscal policy apply styptic. $Y *$ Level balance will not change but will only change the exchange rate. If we had a closed economy, the opposite will happen, fiscal policy will have an effect on the level of income.

Monetary policy. Let suppose now that the central bank will increase the money supply. Because of the price level is assumed fixed an increase in the money supply will increase real balances. An increase in real balances will shift the LM curve to the right as shown in Figure No.2. Thus, an increase in money supply will increase revenue and reduce exchange rate.

Although monetary policy influences income in an open economy, does not influence in a closed economy, the monetary transmission mechanism is different. We recall that in a closed economy to an increase in the money supply increases costs because it reduces interest rates and stimulate investment. In a small open economy, domestic interest rate is fixed rate of interest of the world.

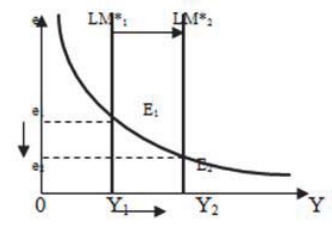

Figure No. 2. Impact of Monetary Policy

A monetary expansion on the flexible interest rate. An increase in the money supply shifts $L M$ curve to the right, the exchange rate decreases and income increases. According to money supply growth is pressured to decrease domestic interest rate and capital flows out of the economy, as investors seeking high income from them. This prevents the outflow of capital domestic interest rates fall. Besides that capital inflows increased domestic money supply in the market of foreign money in exchange. In this way the exchange rate will decrease. Decrease in the exchange rate makes domestic goods relatively cheaper than foreign goods, and through this stimulates exports. Thus, in a small open economy, monetary policy influences income by altering exchange rates rather than interest rates.

Including BP curve will have this model: 
- The monetary policy of flexible exchange regime

- An expansionary monetary policy will shift the LM curve to the right of the LM2 level1.

In a closed economy equilibrium will set in $b$.

In an open economy with a flexible exchange rate regime will have declining interest rate which will bring about a devaluation of the exchange rate and shift the BP curve below (Fig. No. 3)

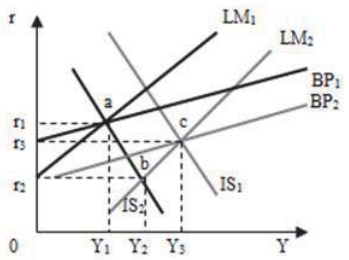

Figure No. 3. Monetary expansion in a flexible exchange rate regime

Exchange rate depreciation will increase exports and reduce imports. This growth in aggregate demand will shift the IS curve to the right. The new balance will be placed at the point where LM2 = c is1 = BP2 in point c. In this way, monetary policy can have a substantial effect on the level of national income in a flexible exchange rate regime.

According to Sanjay Rode in Advanced Macroeconomics. The effects of monetary and fiscal policy are as follows:

\section{Fiscal Policy Effect}

When the government applies an expansionary fiscal policy, it reduces direct taxes, indirect or increased spending on various infrastructure schemes. Exports increase due to the export policy led by the government. However, an expansionary fiscal policy of interest rate increases, leading to an appreciation of the domestic currency. This policy reduces exports and increases imports. The effect of shrinking private investment will not occur because the appreciation of the exchange rate will lead to a decline in exports. With a fixed exchange rate, production will increase, but when the local currency appreciated, will increase the demand for foreign goods by reducing demand for domestic goods.

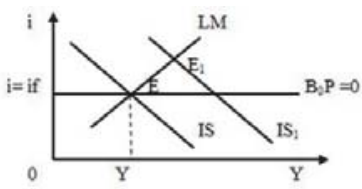

Figure No. 4. The effects of expansionary fiscal policy in an open economy

Figure 4 shows the curves IS-LM equilibrium at point E. IS curve shifts to the right because of export increased. Export growth leads to an increase in revenue. The new equilibrium is achieved in E1. At the point E1, the balance of payments is not in balance. At this point, the exchange rate reassessed. The domestic interest rates are higher than international interest rates, and this increased capital inflows. The economy will shift back to the point of equilibrium $\mathrm{E}$

\section{The Effect Monetary Policy}

Expansionist monetary policy, increases the stock of money in circulation. Low interest rates, and increase revenues. Exchange rate depreciate and becomes more competitive the exports. Export demand grows. The figure shows that an expansionary monetary policy shifts LM from level 1 and reduces the rate of interest in $E^{\prime}$. The interest rate falls below the rate of foreign interest. With this low interest rate, capital flows in economy pulled out. Exchange rate depreciated to the point, that leads to increased import prices. Domestic goods become more competitive and consequently give rise to production. IS curve shifts to the right in IS1, to the point of exchange rate depreciation. Demand and production grow at the level of $\mathrm{E}$ '. The conclusion is that an expansionary monetary policy by lowering the current account improves the required interest rate. 


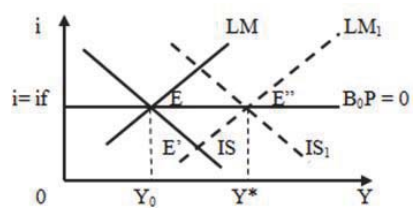

Figure No. 5. The effects of expansionary monetary policy in an open economy

It is suggested that large capital inflows and regimes less flexible exchange rate cycles tend to aggravate the country's credit rating. The fact that the exchange rate regime is statistically significant, despite control capital inflows shows that the impact of exchange rate flexibility is possible and effective. (Magud et.al. 2011). as follows.

According to Bernier and Yves Bernard Simon in Initiation in macroeconomic. The effects of economic policy are

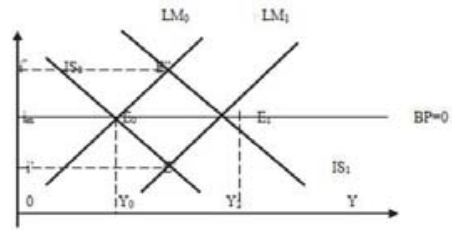

Figure No. 6. The impact of economic policies in IS-LM model of the floating exchange rate regime

This graph represents the basis of the analysis of economic policy with flexible exchange rates, with the assumption of perfect capital mobility. An expansionary monetary policy shifts in level $1 \mathrm{LM}_{0}$ therefore the interest rate will decrease by $\mathrm{I}_{\mathrm{m}}$ in the 'encouraging capital outflows. Therefore the exchange rate will fall, will increase exports by shifting IS $\mathrm{S}_{0}$ curve in IS ${ }_{1}$. So monetary policy has a real significant effect, that is not the case as the budgetary policies. An expansionary budget policy shifts in $I_{1}$ the $I_{0}$ curve and simultaneously increased the interest rate on the "balanced point of" This increase will provoke a capital inflow and an appreciation of the exchange rate which would cut exports by $\mathrm{IS}_{1}$ made curve return to IS 0 . This adjustment process continues for as long as the interest rate is above the foreign domestic.

General Conclusion: In a small open economy with flexible exchange rates moderated policies have a fundamental effect on the growth of the economy while fiscal policies have effect in low and short-term.

Tabele No. 1. Correlation among macroeconomic factors

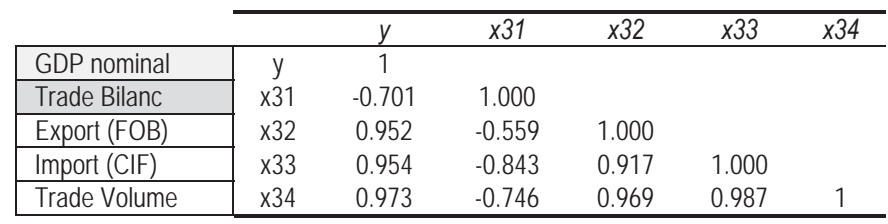

Table No. 2. Correlation link among macroeconomic factors

\begin{tabular}{|c|c|c|c|c|c|}
\hline & & & & & \\
\hline & & $Y$ & $X 1$ & $X 2$ & $X 3$ \\
\hline Real GDP in \% & $\mathrm{Y}$ & 1 & & & \\
\hline $3 \mathrm{M}$ Treasury Bonds rate & $\mathrm{X} 1$ & 0.649487 & 1 & & \\
\hline $6 \mathrm{M}$ Treasury Bonds rate & $\mathrm{X} 2$ & 0.715883 & 0.979578 & 1 & \\
\hline $12 \mathrm{M}$ Treasury Bonds rate & $\mathrm{X} 3$ & 0.666293 & 0.977319 & 0.988715 & 1 \\
\hline
\end{tabular}


Graphic No. 7. Correlation link among macroeconomic factors

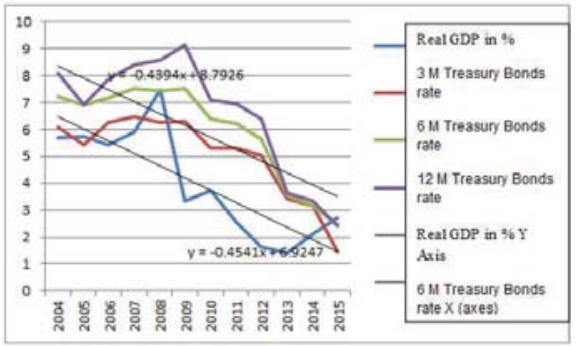

Table No. 3. Correlation among macroeconomic factors (\% growth)

\begin{tabular}{|c|c|c|c|c|c|}
\hline & & & & & \\
\hline & \multicolumn{2}{|r|}{$x 3$} & $x 2$ & \multirow[t]{2}{*}{$X 1$} & $\bar{Y}$ \\
\hline Deficit (\% change) & $\mathrm{X} 3$ & 1 & & & \\
\hline Trade Balance (\% change) & $\mathrm{x} 2$ & 0.054248 & 1 & & \\
\hline Exchange rate Euro/ALL (\% change) & $\mathrm{X} 1$ & -0.19843 & -0.34234 & 1 & \\
\hline GDP (\% change) & Y & -0.27622 & 0.449969 & 0.053799 & 1 \\
\hline
\end{tabular}

Graphic No. 8. Correlation among macroeconomic factors

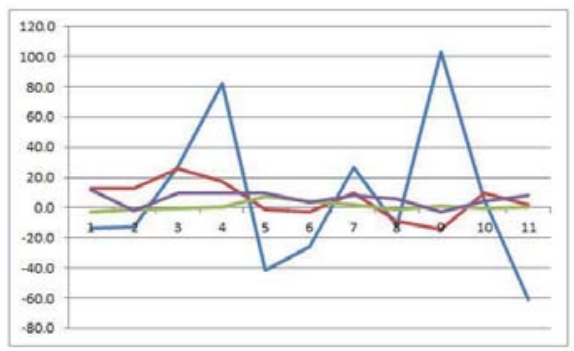

\section{Graphic No. 8.1}

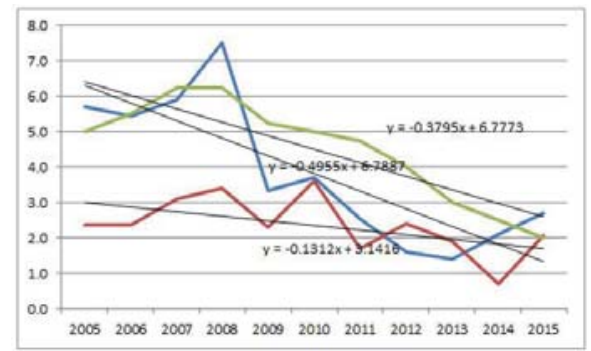

Table No. 4. Macroeconomic factors 2005-2015 in Albania

\begin{tabular}{|l|c|c|c|c|c|c|c|c|c|c|c|}
\hline & $\mathbf{2 0 0 5}$ & $\mathbf{2 0 0 6}$ & $\mathbf{2 0 0 7}$ & $\mathbf{2 0 0 8}$ & $\mathbf{2 0 0 9}$ & $\mathbf{2 0 1 0}$ & $\mathbf{2 0 1 1}$ & $\mathbf{2 0 1 2}$ & $\mathbf{2 0 1 3}$ & $\mathbf{2 0 1 4}$ & $\mathbf{2 0 1 5}$ \\
\hline Real GDP in \% & 5.7 & 5.4 & 5.9 & 7.5 & 3.35 & 3.71 & 2.55 & 1.62 & 1.39 & 2.1 & 2.7 \\
\hline Inflation \% & 2.37 & 2.37 & 3.1 & 3.4 & 2.3 & 3.6 & 1.7 & 2.4 & 1.9 & 0.7 & 2.06 \\
\hline REPO, \% & 5 & 5.5 & 6.25 & 6.25 & 5.25 & 5 & 4.75 & 4 & 3 & 2.5 & 2 \\
\hline Exchange rate in \% & -2.7 & -1.0 & -0.4 & 0.2 & 7.6 & 4.3 & 1.8 & -0.9 & 0.9 & -0.2 & 0.0 \\
\hline GDP nominal in \% & 11.6 & -2.0 & 9.2 & 9.5 & 9.7 & 3.6 & 8.0 & 5.3 & -2.5 & 4.2 & 8.4 \\
\hline
\end{tabular}


Components of GDP are C=costs for purchase of final goods and services, l=gross business investment, $\mathrm{G}=$ government purchases and $\mathrm{NX}=$ net exports (trade balance).

Net exports (NX) or Trade Deficit are one of the components of GDP. When NX increase affects declining GDP and vice versa. Which are the factors that affect the NX? In NX impact, internal fiscal policy, external fiscal policies, exchange rate, etc.

-EU Policies are expansionary fiscal and styptic. Then when expansionary policies have budgetary costs or reduced increase taxes, or both. Expansionary fiscal policy impact in the savings and increased government spending. Reduce the savings would increase the trade deficit for $S=Y-C-G$. Any increase in $G$ and $C$ leads to the decline of $S$. Decreased $S$ invariably leads to the growth of the trade deficit $(S-I=N X)$. Tax breaks available increased personal income (PI). NI growth rose $\mathrm{C}$ consequently lowered savings. Reduce the savings would increase the trade deficit.

The same effect has also increased investment. An increase in the $S$ investment invariably leads to increased trade deficit.

Exchange rate. When the local currency appreciated, increased imports and reduced net exports, or widen the trade deficit. When depreciate the local currency increased exports and lower the trade deficit. Expansionist government policies affecting the growth of the trade deficit.

What concrete connection have between the Albanian economy and the above indicators?

The connection between: Trade Deficit and GDP, GDP and Export, Import and GDP, GDP and savings, investments and GDP, GDP and Exchange Rate.

\section{Conclusion and Recommendations}

Monetary policy affects more in a Small Open Economy, with flexible exchange rate regime. Fiscal policy has less impact and temporary.

\section{References}

Ministry of Finance. Fiscal indicators. October 2014

Ministry of Finance. FISCAL INDICATORS REGARDING CONSOLIDATED BUDGET 1993-2010.

Ministry of Finance. REVENUES REGARDING CONSOLIDATED BUDGET 1993-2010

Ministry of Finance. REVENUES REGARDING CONSOLIDATED BUDGET 2011-2015.

Official Bulletin. 1992-2013. Parliament of Albania.

Bank of Albania. Statistical Report, May 2016.

Bank of Albania. Statistical Report 2014.

Bank of Albania. Statistical Report 2012.

Bank of Albania. Statistical Report 2010.

Bank of Albania. Statistical Report 2008.

Bank of Albania. Statistical Report 2006. 